\title{
Solar Energy Recovery and Storage System for Powering Wireless Communicating Nodes
}

\author{
Salick Diagne1, Abdou Karim Farota1, Ognadon Assogba', Bouya Diop", Thierry Val ${ }^{2}$ \\ ${ }^{1}$ Gaston Berger University, Saint-Louis, Senegal \\ ${ }^{2}$ IRIT, University of Toulouse 2, Toulouse, France \\ Email: abdou-karim.farota@ugb.edu.sn,diagne.salick@ugb.edu.sn
}

How to cite this paper: Diagne, S., Farota, A.K., Assogba, O., Diop, B. and Val, T. (2021) Solar Energy Recovery and Storage System for Powering Wireless Communicating Nodes. Energy and Power Engineering, 13, 377-391.

https://doi.org/10.4236/epe.2021.1312026

Received: September 30, 2021

Accepted: December 4, 2021

Published: December 7, 2021

Copyright () 2021 by author(s) and Scientific Research Publishing Inc. This work is licensed under the Creative Commons Attribution International License (CC BY 4.0).

http://creativecommons.org/licenses/by/4.0/

\begin{abstract}
We find nowadays in several fields of application the presence of IoT technology such as wireless sensor and actuator networks. In this technology, one of the main points of study is the management of energy consumption. In this article, we provide a solar energy harvesting and storage system for powering wireless nodes. The system we propose uses a low power solar pane a P \& O control adapted to fuzzy logic for the MPPT. For energy storage, we used the supercapacitor technology. The simulation of the models shows better results than using the $\mathrm{P} \& \mathrm{O}$ command for an autonomous power supply of the wireless communicating nodes in the study region.
\end{abstract}

\section{Keywords}

Solar Energy, Energy Recovery, Supercapacitor, Fuzzy Logic

\section{Introduction}

This study is part of a project to protect Senegal's rice fields against grain-eating birds using wireless sensors and actuators. In this wireless communication technology between objects, energy consumption is a crucial point. Indeed, it defines the lifespan of applications based on this technology. There are several ways to optimize this energy consumption or to provide additional energy. In this study, we present a system to collect and store solar energy in order to provide additional energy to wireless communicating nodes. The choice of this energy is motivated by its freedom and its availability in the study environment which is in the north of Senegal. Indeed, in Senegal, we have significant solar energy potential available with around 3000 hours of sunshine per year and an overall irradiation of $5.8 \mathrm{kWh} / \mathrm{m}^{2} /$ day [1]. In particular in our study area 
(Saint-Louis region) in northern Senegal, we have significant solar potential.

Thus, to eliminate batteries in order to extend the lifespan of IoT-type applications and prevent environmental pollution due to the waste of used batteries, solar energy recovery is an excellent alternative in general, particularly in Senegal.

\section{Modelling of the Photovoltaic Generator}

In this section, we are interested in modelling the photovoltaic generator (PVG) to be used to power our wireless nodes. A photovoltaic generator or photovoltaic panel is an association of identical solar cells in series and/or in parallel [2] [3] [4].

\subsection{Model of the Photovoltaic Cell}

We use the cell model with five parameters $\left(I_{p h}, I_{s a t}, R_{s}, R_{s h}\right.$ and $\left.N_{s}\right)$. This model is considered to be the most realistic (than three or four parameters) because it takes into account more real parameters including possible losses (Figure 1). Usually, this single model is enough to model a PVG [5] that is why it is used in several studies as in [2] and [6].

The current supplied by the cell for this model is given by Equation (1).

$$
\begin{gathered}
I_{c}=I_{c c} \frac{E}{E_{0}}-I_{\text {sat }}\left(\exp \left(\frac{V_{c}+R_{s} \cdot I_{c}}{V_{T}}\right)-1\right)-\frac{V_{c}+R_{s} \cdot I_{c}}{R_{s h}} \\
V_{T}=\frac{n K T}{q}
\end{gathered}
$$

With $I_{c}$ cell current, $E_{0}$ the sunshine intensity under standard conditions $\left(E_{0}=\right.$ $\left.1000 \mathrm{Wm}^{-2}\right), V_{c}$ cell voltage, $I_{s c}$ short-circuit current of the cell, $I_{s a t}$ inverse saturation current of the diode and $V_{T}$ thermodynamic potential (Equation (2)) such that $n, K, T$ and $q$ are respectively the idealist factor of the diode, the Boltzmann constant, the temperature of the $\mathrm{PN}$ junction and the charge of the electron.

\subsection{Modelling the Current-Voltage Characteristic of the Generator}

We have defined above that a photovoltaic generator (Figure 2) is a set of photovoltaic cells associated in series and/or in parallel.

Thus, by considering Equation (1), we can determine the current-voltage characteristic of our photovoltaic generator by Equation (3).

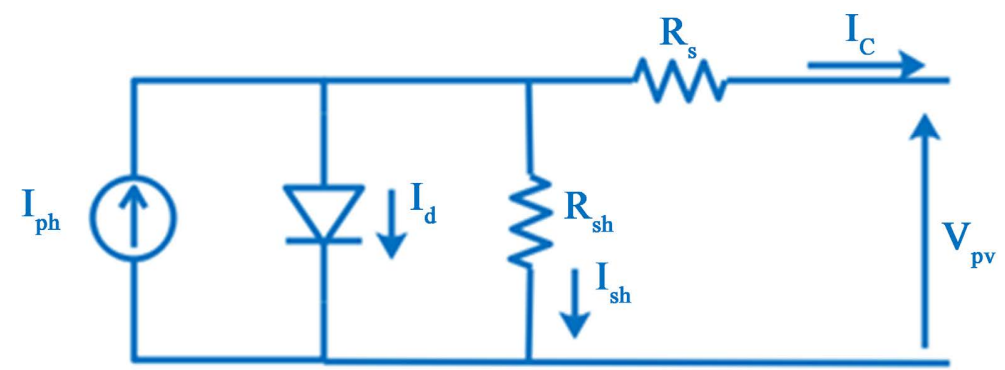

Figure 1. Five parameter cell model for one cell. 


$$
I_{p v}=N_{p} \frac{E \cdot I_{c c}}{E_{0}}-I_{s a t}\left(\exp \left(\frac{V_{p v}}{N_{s} \cdot V_{T}}+\frac{R_{s} \cdot I_{p v}}{N_{p} \cdot V_{T}}\right)-1\right)-\frac{\frac{N_{p} \cdot V_{p v}}{N_{s}}+R_{s} \cdot I_{p v}}{R_{s h}}
$$

\subsection{Modelling of the Power-Voltage Characteristic of the Generator}

The model of the power-voltage characteristic is given by Equation (4).

$$
\begin{aligned}
& P_{p v}=N_{s} \cdot I_{p v} \cdot V_{c} \\
& =\left(N_{p} \frac{E \cdot I_{c c}}{E_{0}}-I_{s a t}\left(\exp \left(\frac{V_{p v}}{N_{s} \cdot V_{T}}+\frac{R_{s} \cdot I_{p v}}{N_{p} \cdot V_{T}}\right)-1\right)-\frac{\frac{N_{p} \cdot V_{p v}}{N_{s}}+R_{s} \cdot I_{p v}}{R_{s h}}\right) N_{s} \cdot V_{c}
\end{aligned}
$$

With $P_{p w} I_{p v}$ and $V_{c}$ are, respectively, the power, the current of the solar panel as well as the voltage of the solar cell.

\subsection{Solar Panel Simulation}

Figure 3 shows the current-voltage and power-voltage characteristic of our photovoltaic generator. These simulation results are obtained under standard conditions $\left(E=1000 \mathrm{~W} / \mathrm{m}^{2}\right.$ at a temperature of $\left.25^{\circ} \mathrm{C}\right)$ with $N_{S}=10$ and $N_{P}=1$.

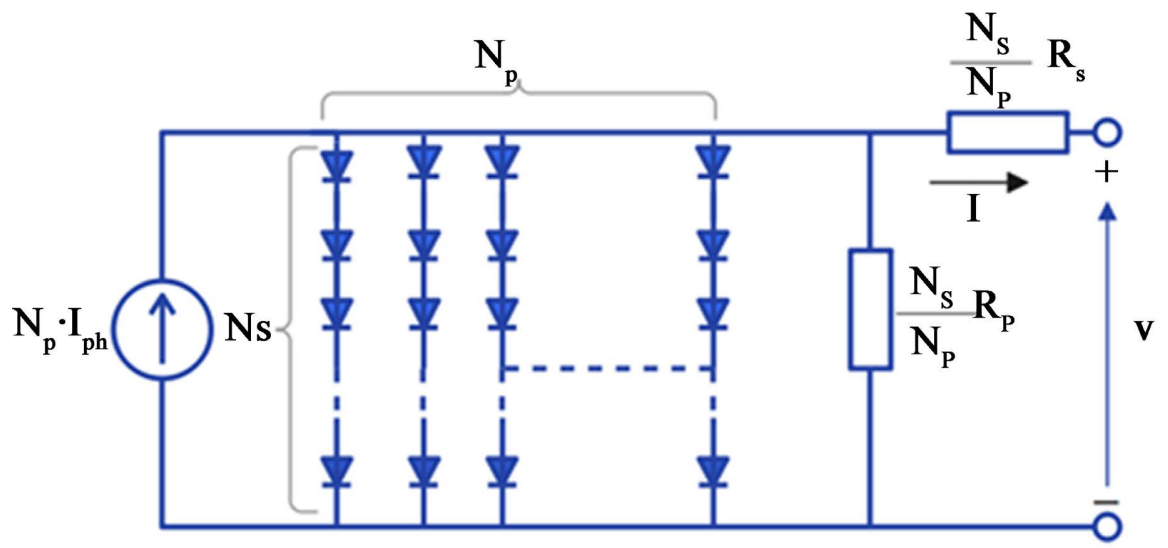

Figure 2. General model of the photovoltaic panel.
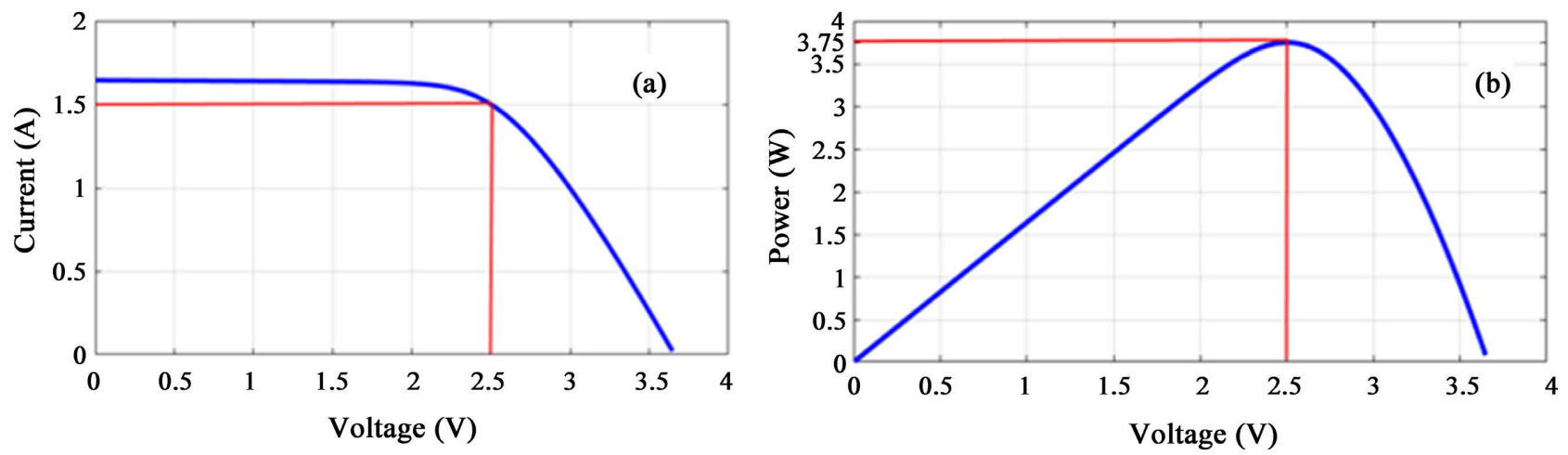

Figure 3. Current-voltage (a) and power-voltage (b) characteristic of the photovoltaic generator. 


\section{Conversion and Storage of Solar Energy Recovered}

\subsection{Conversion and Adaptation of the Energy}

There are several techniques or photovoltaic conversion chain for supplying a load. In our case the load is a sensor or actuator node therefore requiring a direct current (DC). Thus, to ensure at any time a transfer of the maximum power available at the PVG level to the load, we used a technique which consists in inserting an adaptation stage between the PVG and the load. This adaptation stage consists of a static DC-DC converter controlled by a PPM tracking mechanism, "Maximum Power Point Tracking" (MPPT) as shown in Figure 4.

However, with this configuration, although the maximum power is transmitted, it does not offer any autonomy for the charge. So, we need a storage device that will allow the load to have some autonomy. For this, we have chosen to use supercapacitors, which we will come back to later. One of the disadvantages of using supercapacitors for our application is that their output voltage depends on their state of charge. While the load of our application needs a fixed $3.3 \mathrm{~V}$ power supply. To overcome this constraint, we also decided to insert a $3.3 \mathrm{~V}$ Buck-Boost regulator with very good efficiency in order to maintain a fixed supply voltage of the load to $3.3 \mathrm{~V}$.

Thus, the complete system that we propose is presented in Figure 5. It includes a

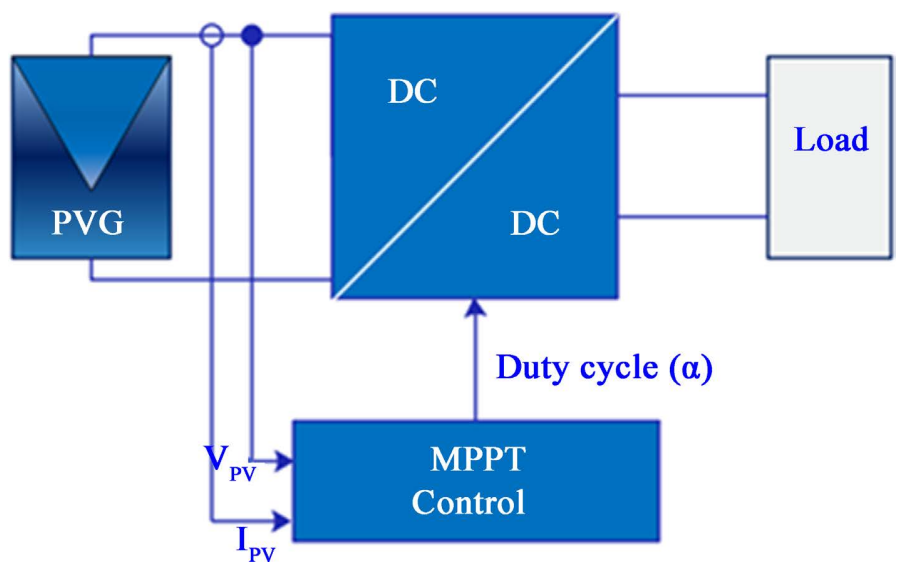

Figure 4. Block diagram of a photovoltaic system with converter (DC/DC) controlled by a control (MPPT) to charge (DC).

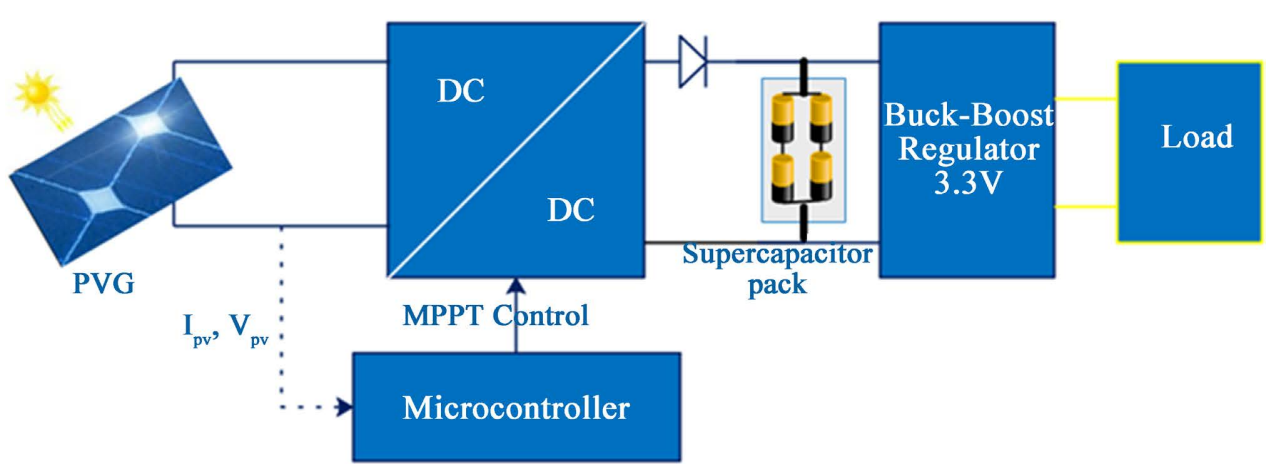

Figure 5. Architecture of the proposed energy management system. 
photovoltaic generator (PVG), a static converter (DC-DC), an MPPT controller, a supercapacitor pack and a Buck-Boost regulator.

With this new configuration, part of the recovered energy is used to supply the load via the regulator. The other part is stored in supercapacitors allowing the application to have autonomy in the event of a brief absence of solar radiation.

\subsubsection{The DC-DC Converter}

The static converter we use is a chopper. It can control the transfer of energy between a continuous electrical source and a continuous electrical load with flexibility and high efficiency. This energy control is obtained through the use of a switch controlled in opening and closing (MOSFET transistor, bipolar transistor, tristor).

Three types of choppers are mainly used in photovoltaic adaptation, the booster chopper (boost), the chopper Buck and the chopper buck-boost. In our case, a small-sized PVG (similar to the dimensions of wireless sensor nodes) is used to supply the sensors. We assume from these dimensions that the voltage at the maximum power point is less than the supply voltage of the sensor node. So here, the DC-DC converter will be a Boost Chopper. Its role is to convert the DC input voltage $\left(V_{P V}\right)$ to another DC output voltage ( $\left.V_{\text {boost }}\right)$ of greater value. This allows the sensor and the power supply circuit to be supplied or the supercapacitors to be recharged (with a maximum voltage of $5 \mathrm{~V}$ ). Figure 6 represents the equivalent electrical circuit of the converter.

The relation between the output voltage and the input voltage is given by Equation (5). This relation follows from the modelling of the operating principle of a Boost chopper.

$$
V_{s}=\frac{V_{e}}{1-\alpha}
$$

With $\alpha$ a value between 0 and 1 , is the fraction of period during which the transistor conducts.

\subsubsection{MPP Pursuit Techniques}

The sunshine and temperature variations require a continuous adjustment of the maximum power point (MPPT) of the PVG. This adjustment makes it possible to extract the maximum power from the PVG at all times. To achieve this function, several MPPT algorithms have been developed. We cite here those which are the most used, they are in particular: commands "Perturb \& Observe (P \& O)",

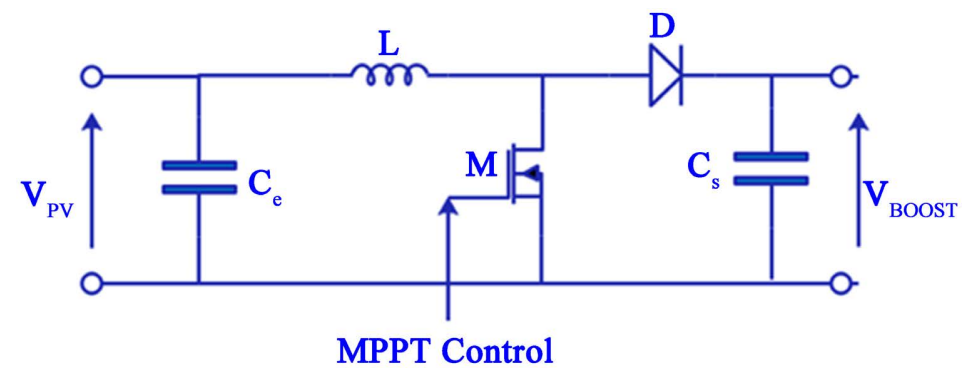

Figure 6. Equivalent circuit of the booster chopper. 
increment of conductance (IncCond), "Hill Climbing" and those based on relations of proportionality (Fraction of $V_{O C}$ and $I_{C c}$ ). These algorithms differ according to the type of electronic implementation (analog, digital or mixed), the input and output parameters of the MPPT command and the types of calculations they perform [7]. More recently, artificial intelligence techniques are used more and more, in particular fuzzy logic but also neural networks. In our study, we consider the perturb and observe ( $\mathrm{P} \& \mathrm{O})$ command. This is the command most used in MPPT research because of its simplicity of implementation. However, it has drawbacks, notably its slow convergence during a sudden change in irradiation and its permanent oscillations around the MPP.

Thus, to optimize the performance, we chose to combine it with the technique of fuzzy logic. This method combining the $\mathrm{P} \& \mathrm{O}$ technique and fuzzy logic is presented below.

\section{Artificial Intelligence Techniques for the MPPT}

The disadvantages of using the $\mathrm{P} \& \mathrm{O}$ technique alone have opened up other tracks for MPP research. Among these avenues, artificial intelligence (AI) techniques are increasingly occupying a privileged position. Indeed, although they are old techniques and their use in the research of MPP, recent, they provide better results [8] [9]. Of these AI techniques, artificial neural networks [10] [11] and fuzzy logic are the most used in this MPP research.

\section{MPPT with the P \& O control adapted to fuzzy logic}

The technique we used is an adaptation of the $\mathrm{P} \& \mathrm{O}$ method to the FL. It uses the data $\left(\Delta P_{P V}(k)\right.$ and $\left.\Delta V_{P V}(k)\right)$ provided by the $\mathrm{P} \& \mathrm{O}$ method (Figure 7$)$ to determine the two inputs of the fuzzy logic control. The inputs are on the one hand the errors $e(k)$ (Equation (6)) and on the other hand $\Delta e$ (Equation (7)) as shown in Figure 8.

$$
\begin{gathered}
e(k)=\frac{\Delta P_{P V}(k)}{\Delta V_{P V}(k)} \\
\Delta e=e(k)-e(k-1)
\end{gathered}
$$

The flowchart of this technique is shown in Figure 9. For the fuzzy logic block, we use five fuzzy variables for input and output. These fuzzy variables are: Negative Big (NB), Negative Small (NS), Zero (ZE), Positive Small (PS) and Positive Big (PB) (Figure 10).

To determine the output of the technique as represented in Figure 10, the inputs $(e(k)$ and $\Delta e)$ are first converted into linguistic variables (fuzzification) then the linguistic variable of the output is obtained by searching in a database of rule (Table 1), Mamdani's fuzzy inference system is used. Finally, the defuzzification is used to determine the numerical value of $\Delta D$ we used for that the method of the centre of gravity.

\section{Modelling and Simulations of the Energy Recovery Circuit}

For the validation of our energy recovery system, in particular the adaptation 
part with a command combining P \& O techniques and fuzzy logic (FL), we have developed and simulated the model for wireless sensors (Figure 11 and Figure 12). The modelled solar panel, supplied at the point of maximum power (MPP) a power of PMPP $=3.75$ Watts with VMPP $=2.5$ Volts. The excess power is the losses at the component level. The VMPP voltage is the input voltage of the Booster and the 3.3 Volts regulator. For the simulation, we determined the parameters of the Booster $(2.5 \mathrm{~V} / 5 \mathrm{~V})$, in particular the input and output capacities by Equation (8) and the inductance of the coil by Equation (9) [12] [13] [14].

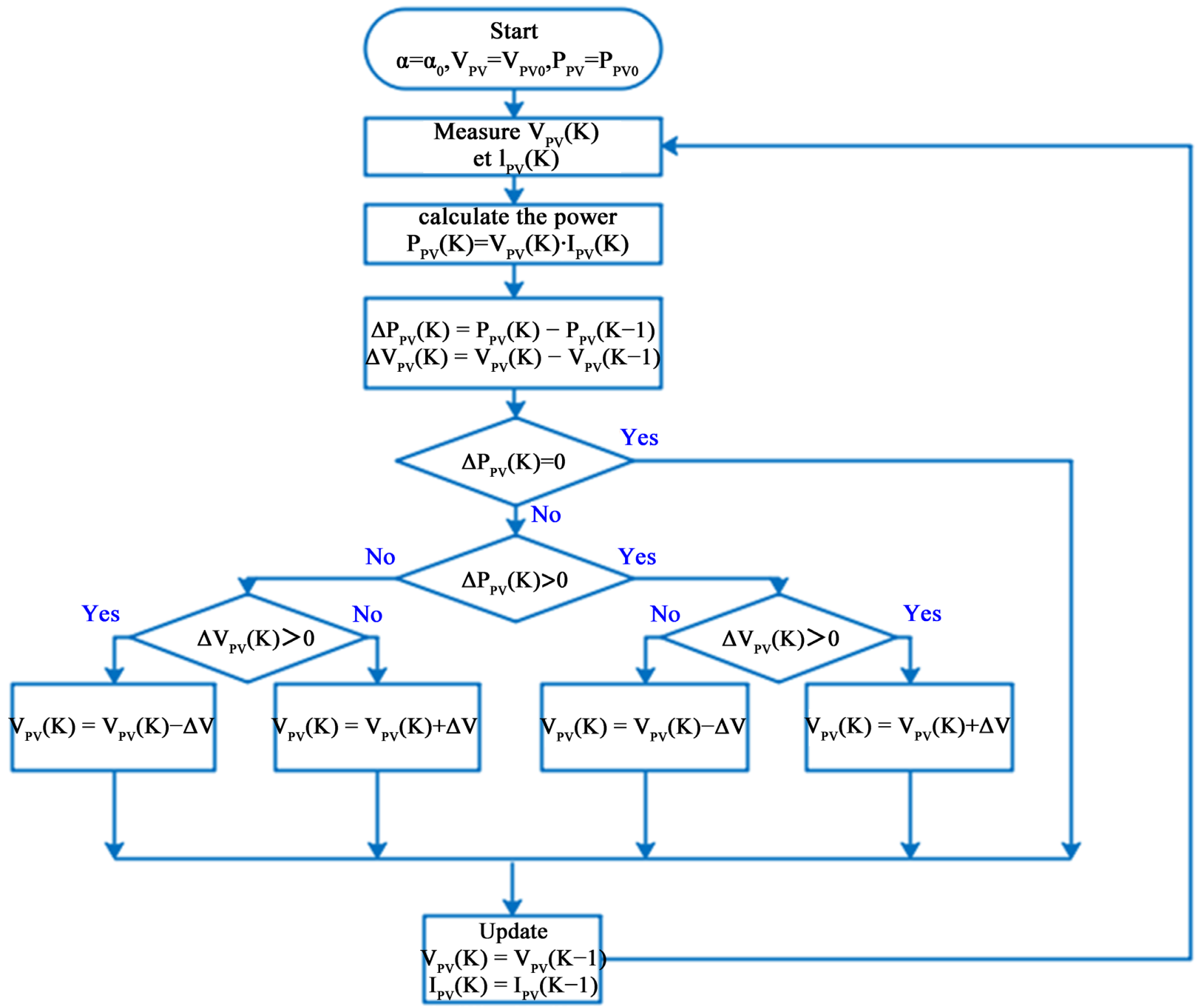

Figure 7. Flowchart of the Perturb \& Observe (P \& O) method.

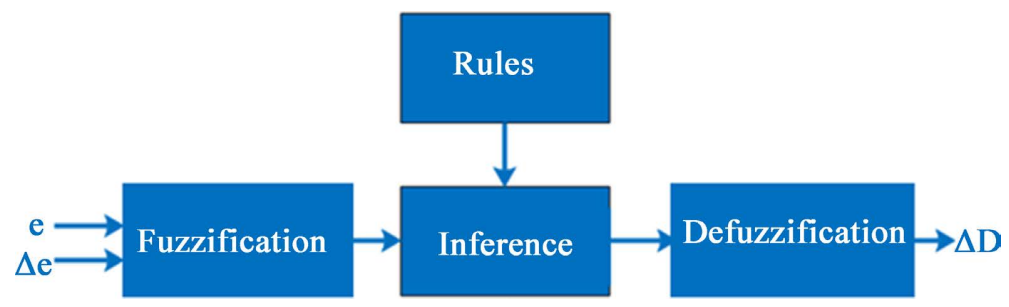

Figure 8. Diagram blocks of the fuzzy logic part. 


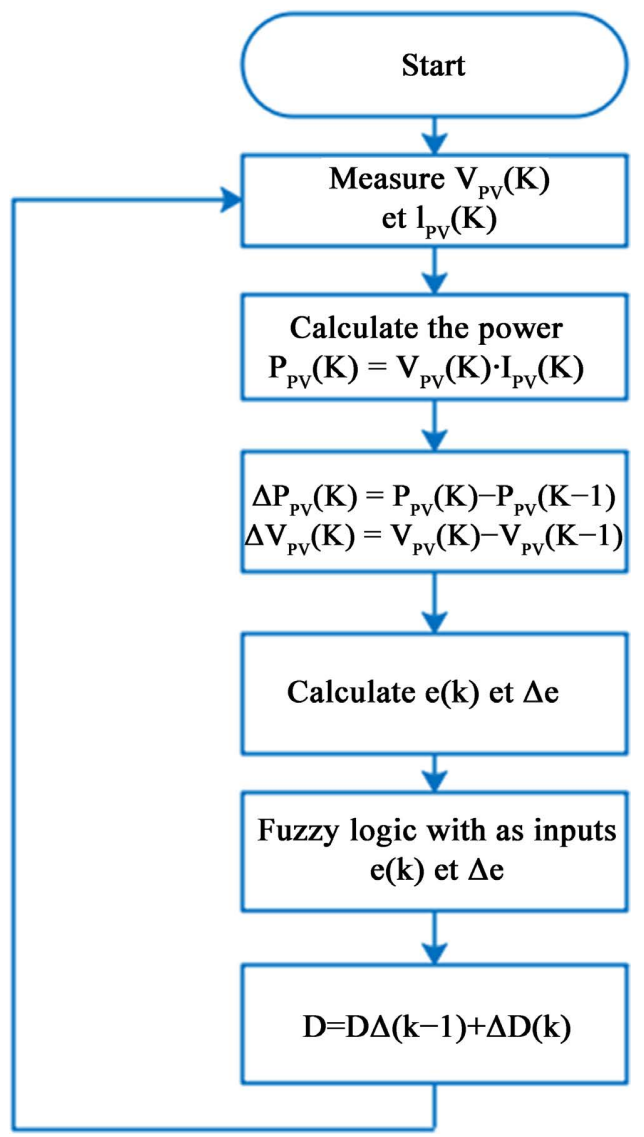

Figure 9. Flowchart of the $\mathrm{P} \& \mathrm{O}$ technique adapted to fuzzy logic.

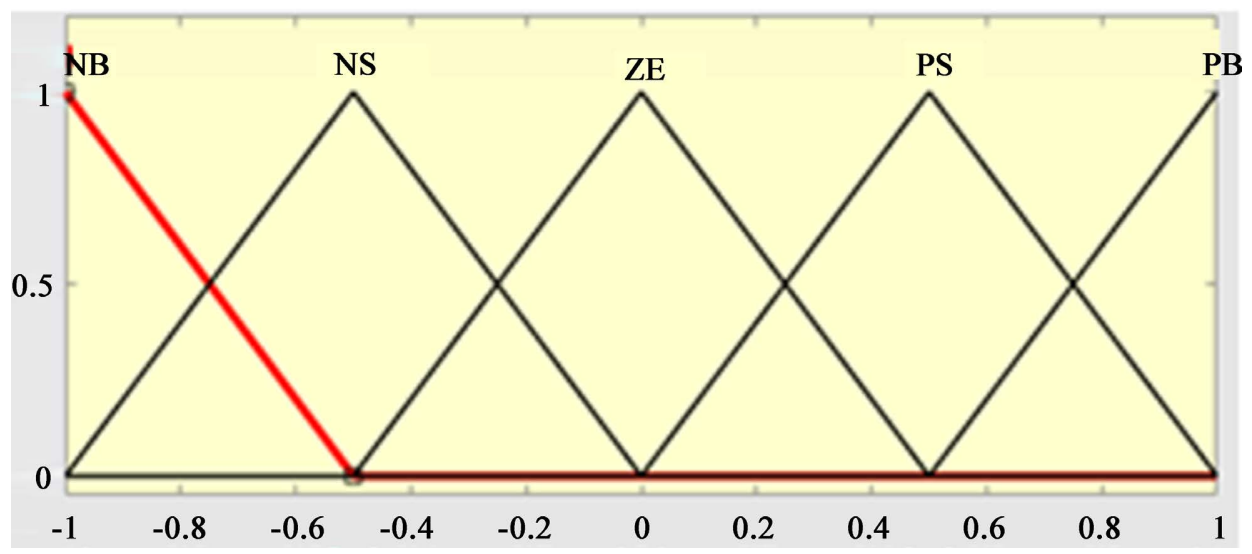

Figure 10. The input and output variables of membership functions.

Table 1. Rules of the P \& O technique adapted to fuzzy logic.

\begin{tabular}{cccccc}
\hline $\mathrm{E} \backslash \Delta \mathrm{E}$ & $\mathrm{N}$ & $\mathrm{ZE}$ & $\mathrm{PS}$ & $\mathrm{P}$ & $\mathrm{PB}$ \\
\hline $\mathrm{N}$ & $\mathrm{ZE}$ & $\mathrm{PS}$ & $\mathrm{P}$ & $\mathrm{PB}$ & $\mathrm{PB}$ \\
$\mathrm{ZE}$ & $\mathrm{ZE}$ & $\mathrm{ZE}$ & $\mathrm{PS}$ & $\mathrm{P}$ & $\mathrm{PB}$ \\
$\mathrm{PS}$ & $\mathrm{N}$ & $\mathrm{ZE}$ & $\mathrm{ZE}$ & $\mathrm{PS}$ & $\mathrm{PS}$ \\
$\mathrm{P}$ & $\mathrm{N}$ & $\mathrm{N}$ & $\mathrm{ZE}$ & $\mathrm{ZE}$ & PS \\
\hline
\end{tabular}




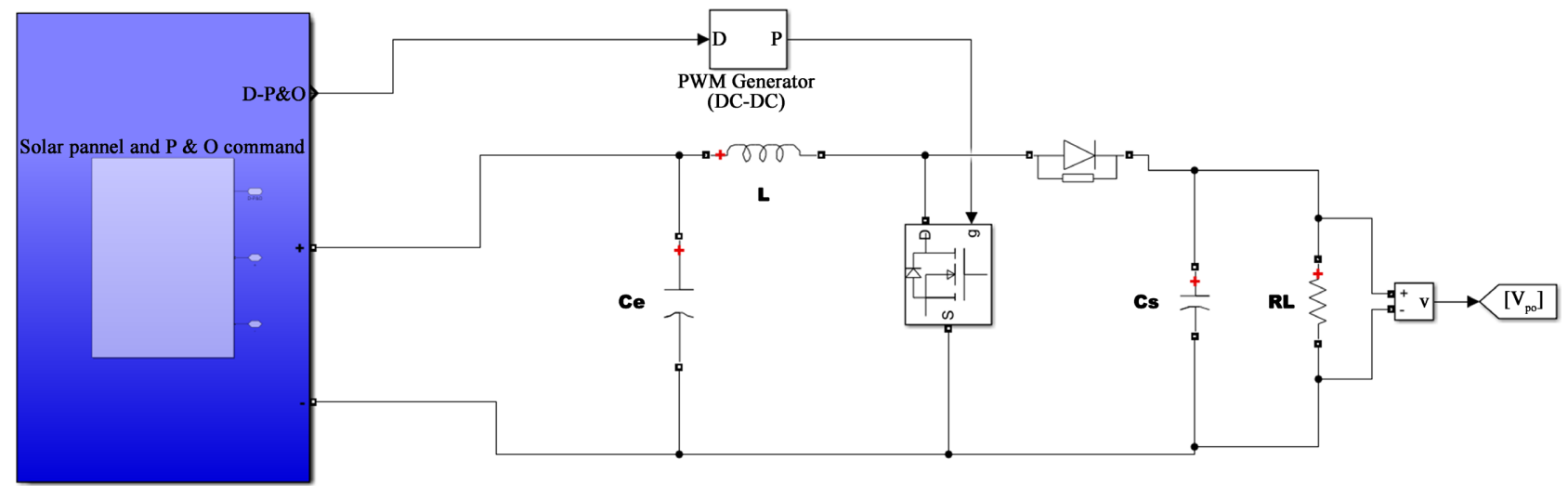

Solar pannel and P \& O command

Figure 11. Adaptation circuit (Booster) simulated with a P \& O control.

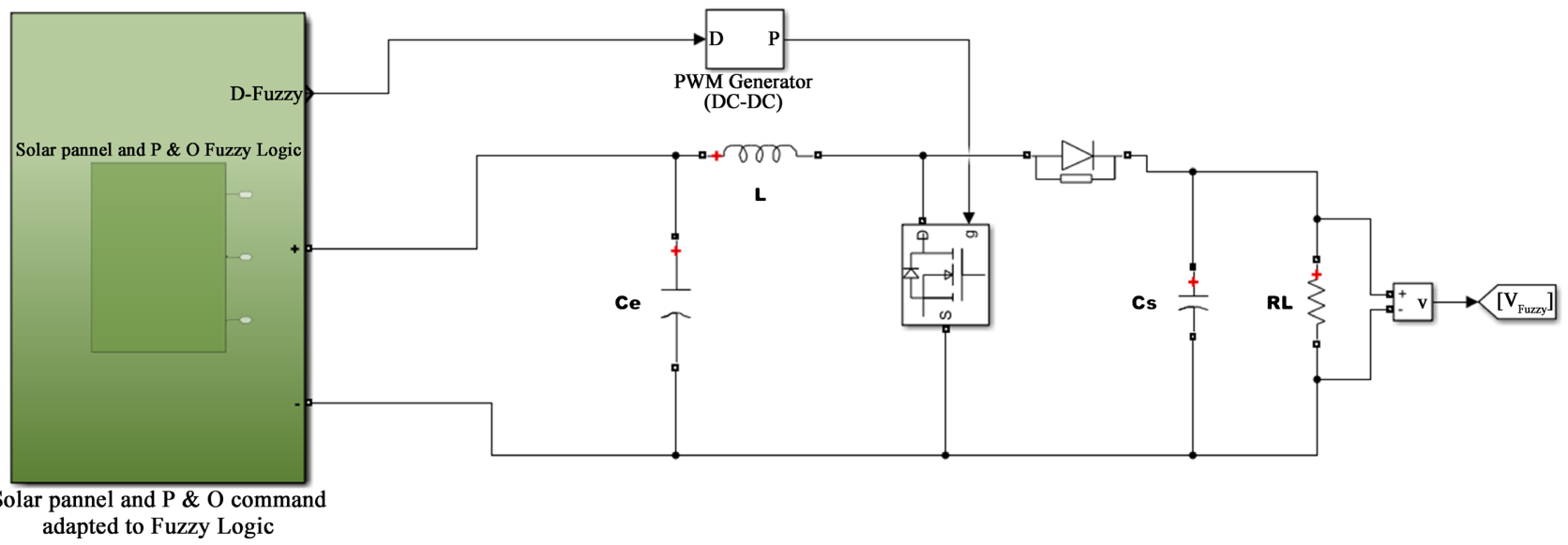

Figure 12. Adaptation circuit (Booster) simulated with a P \& O control adapted to the LF.

$$
\begin{gathered}
C_{\min }=\frac{\alpha V_{\text {Booster }}}{2 \times R_{L} \times f_{s} \times \Delta V_{\text {Booster }}} \\
L_{\min }=\frac{\alpha V_{M P P}}{2 \times \Delta I_{p v} \times f_{s}}
\end{gathered}
$$

With $\Delta V_{\text {Booster }}$ and $\Delta I_{p v}$ being respectively the ripple of the booster voltage and the ripple of the current in the inductor (we chose a $10 \%$ value). Resistor $R_{L}$ represents the load and $f_{s}$ the chopper switching frequency.

The simulation results under standard conditions (irradiation $1000 \mathrm{~W} \cdot \mathrm{m}^{-2}$ at $25^{\circ} \mathrm{C}$ ) are given in Figure 13. These results show on the one hand that the two techniques used follow the voltage at the MPP of the solar panel well. The $5 \mathrm{~V}$ DC voltage indicates that our matching circuit is playing its role as a voltage booster.

The results show on the other hand, that the $\mathrm{P} \& \mathrm{O}$ technique adapted to the FL is more efficient than the classic $\mathrm{P} \& \mathrm{O}$ technique in terms of temporal response. Indeed, the adapted fuzzy logic gives a relatively faster response with a shift of 30.939 milliseconds compared to the conventional P \& O technique. This adapted technique also turns out to be the most stable in terms of oscillation 


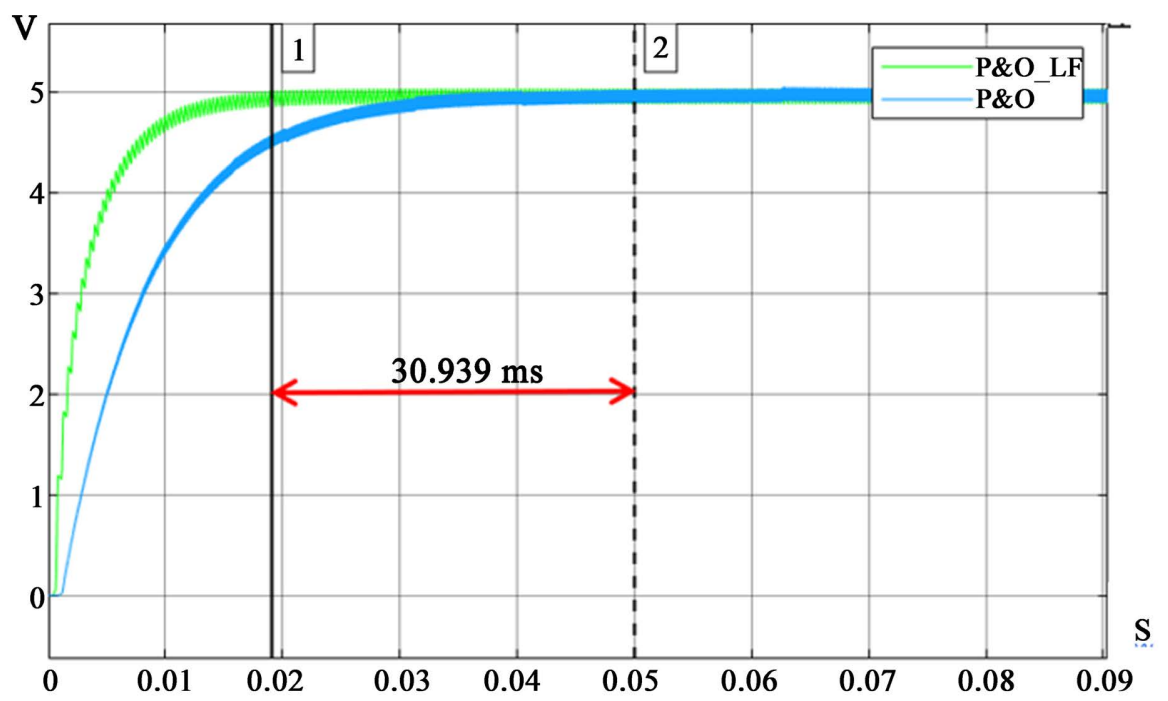

Figure 13. Results of simulations with classic P \& O commands and P \& O combined with LF.

around the MPP, mainly because of the intermediate and non-binary values that the fuzzy logic variables use.

\section{Storage of Recovered Energy}

The sensor nodes that we want to power need constant and continuous voltage and power. However, the solar energy recovered by our photovoltaic generator is dependent on weather conditions (sunshine, temperature, etc.) and is therefore not stable. Hence the need for an energy storage system to ensure the continuity of the power supply if a brief absence of irradiation occurs.

In our study, we considered supercapacitor technology for storing recovered solar energy. We chose this technology because it is notably the most recent with a better lifespan [15] [16]. It is less bulky but also with temperature ranges better suited to our environment. However, supercapacitors are limited by the maximum voltage of a cell which is around $2.7 \mathrm{~V}$ in a fully charged state. To overcome this limitation, the supercapacitors are typically connected in series to increase voltage (these are the packs of supercapacitors).

\subsection{Supercapacitor Modelling}

We chose to study the supercapacitor the first order model (a branch) [17]. This model is also called a constructor model because it is also offered by the manufacturers. It is identical to the model of the electrolytic capacitor. With this model, a supercapacitor is represented by a simple RC circuit (Figure 14), $R$ represents the equivalent series resistance reflecting the losses by Joule effect in the supercapacitor and $C$ its main capacitance. This model does not take into account the influence of the charge voltage on the capacitance of the component or the phenomenon of redistribution of internal charges in the supercapacitor.

The equivalent series resistance (or ESR), can be determined by means of a 
single test, a charge or discharge of the cell (the elementary supercapacitor to be used) at constant current. Indeed, the effect of this resistance is manifested by a voltage drop that appears when the current flows (Figure 15). Thus, the ESR can be calculated by measuring the voltage drop across the cell when applying a direct current (e.g. discharge) [16] [18]. The resistance value is given by Equation (10).

$$
R_{E S R}=\frac{\Delta U_{E S R}}{I_{d}}
$$

As for the capacity $C$, it is estimated by considering the evolution of the voltage during a given time during a discharge or a charge always at constant current. For a discharge its value is given by Equation (11) [16] [18].

$$
C=I_{d} \frac{\Delta t_{c}}{\Delta U_{s c}}
$$

Measures of work on the supercapacitor PC10 (10F; 2, 5V) of Maxwell [19] give us an overview of the variation of parameters $(R$ and $C$ ) depending on the temperature (Table 2).

\subsubsection{Modelling of the Supercapacitor Pack (SC Pack)}

The SC pack is a combination of $N_{s}$ and/or $N_{p}$ supercapacitors connected respectively

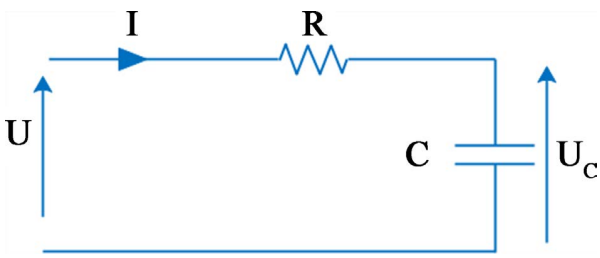

Figure 14. First order supercapacitor model.

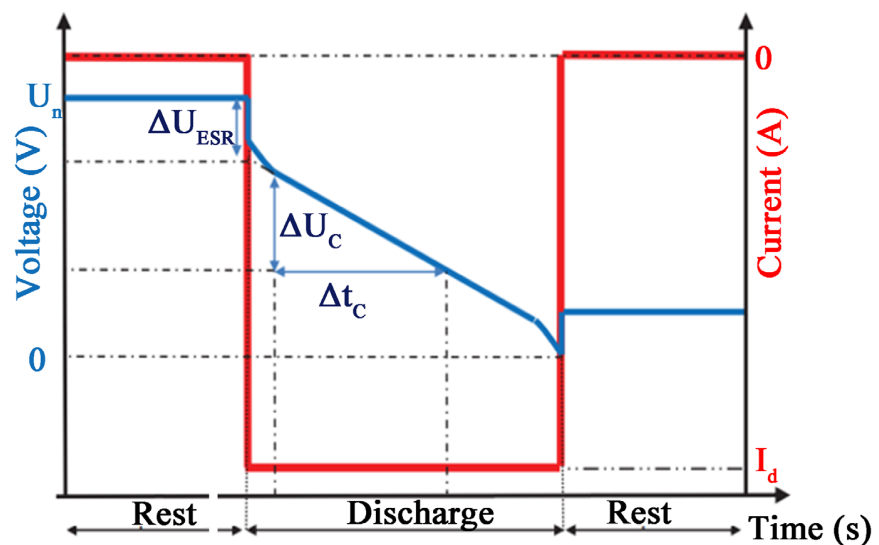

Figure 15. Estimation of the ESR and the capacity of a supercapacitor [20].

Table 2. The $R$ and $C$ parameters of the PC10 supercapacitor.

\begin{tabular}{cccccccccc}
\hline Temperature $\left({ }^{\circ} \mathrm{C}\right)$ & -50 & -40 & -20 & 0 & 25 & 40 & 60 & 80 & 100 \\
Ohmic drop (Ohm) & 0.353 & 0.349 & 0.196 & 0.176 & 0.156 & 0.146 & 0.138 & 0.140 & 0.135 \\
Capacitance (Farads) & 8.152 & 8.809 & 8.913 & 9.250 & 9.251 & 9.175 & 9.191 & 9.145 & 9.140 \\
\hline
\end{tabular}


in series and/or in parallel [20]. Still following our choice of base model, this SC pack is modelled by an equivalent resistor called pack resistor $\left(R_{p a c k}\right)$ in series with an equivalent capacitance $\left(C_{p a c k}\right)$ as shown in Figure 16.

Thus, using Figure 16, we can calculate the resistance and the overall capacity of the pack $\left(R_{p a c k}\right.$ and $\left.C_{p a c k}\right)$ as well as the voltage at the terminals of $C_{p a c k}$ and the intensity of the pack ( $V_{C}$ and $I_{p a c k}$ ) by Formulas (12)-(15).

$$
\begin{gathered}
C_{p a c k}=\frac{N_{p}}{N_{s}} C_{s c} \\
R_{p a c k}=\frac{N_{s}}{N_{p}} R_{E S R} \\
V_{p a c k}=N_{s} V_{s c} \\
I_{p a c k}=N_{p} I_{s c}
\end{gathered}
$$

The energy and the power of the SC pack are given respectively by the two Equations (16) and (17).

$$
\begin{gathered}
E_{p a c k}=\frac{1}{2} C_{p a c k} V_{p a c k}^{2}=\frac{1}{2} N_{p} \cdot N_{s} \cdot C_{s c} \cdot V_{s c}^{2} \\
P_{p a c k}=V_{p a c k} I_{p a c k}-R_{p a c k} I_{p a c k}=N_{p} \cdot N_{s}\left(V_{s c} I_{s c}-R_{E S R} I_{s c}^{2}\right)
\end{gathered}
$$

Knowing the elementary parameters $(R$ and $C$ ), we can determine for this model the number of supercapacitors $N_{s c}$ (Equation (18)) necessary to provide a given power (Pack-useful) by considering Equations (12)-(15).

$$
N_{s c}=N_{p} N_{s}=\frac{2}{1-k^{2}} \frac{E_{u t i l-p a c k}}{C_{s c} V_{s c}^{2}}
$$

To make a compromise between a limited number of supercapacitors due in particular to the requirement of IoT on the size and a fairly long supply time to the brief absence of solar energy, we have developed a model of the pack supercapacitor. So, since we are using the RC model, the $R$ and $C$ parameters of the

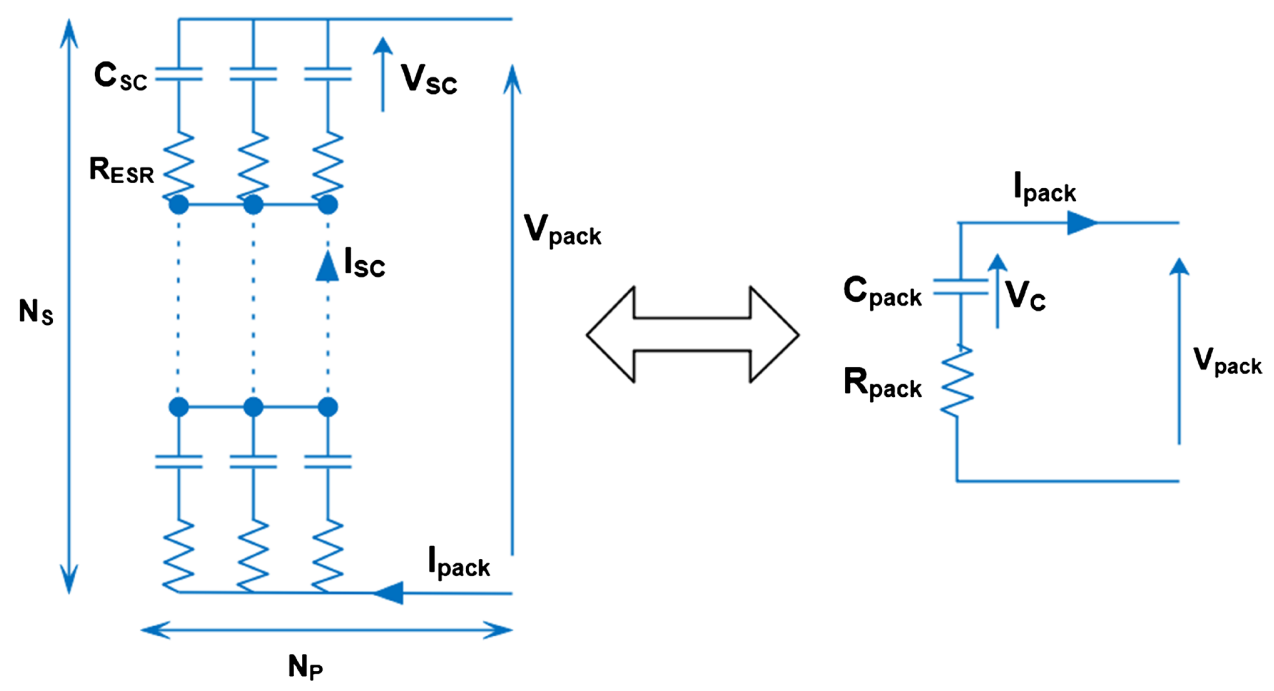

Figure 16. Model of a pack of supercapacitors. 


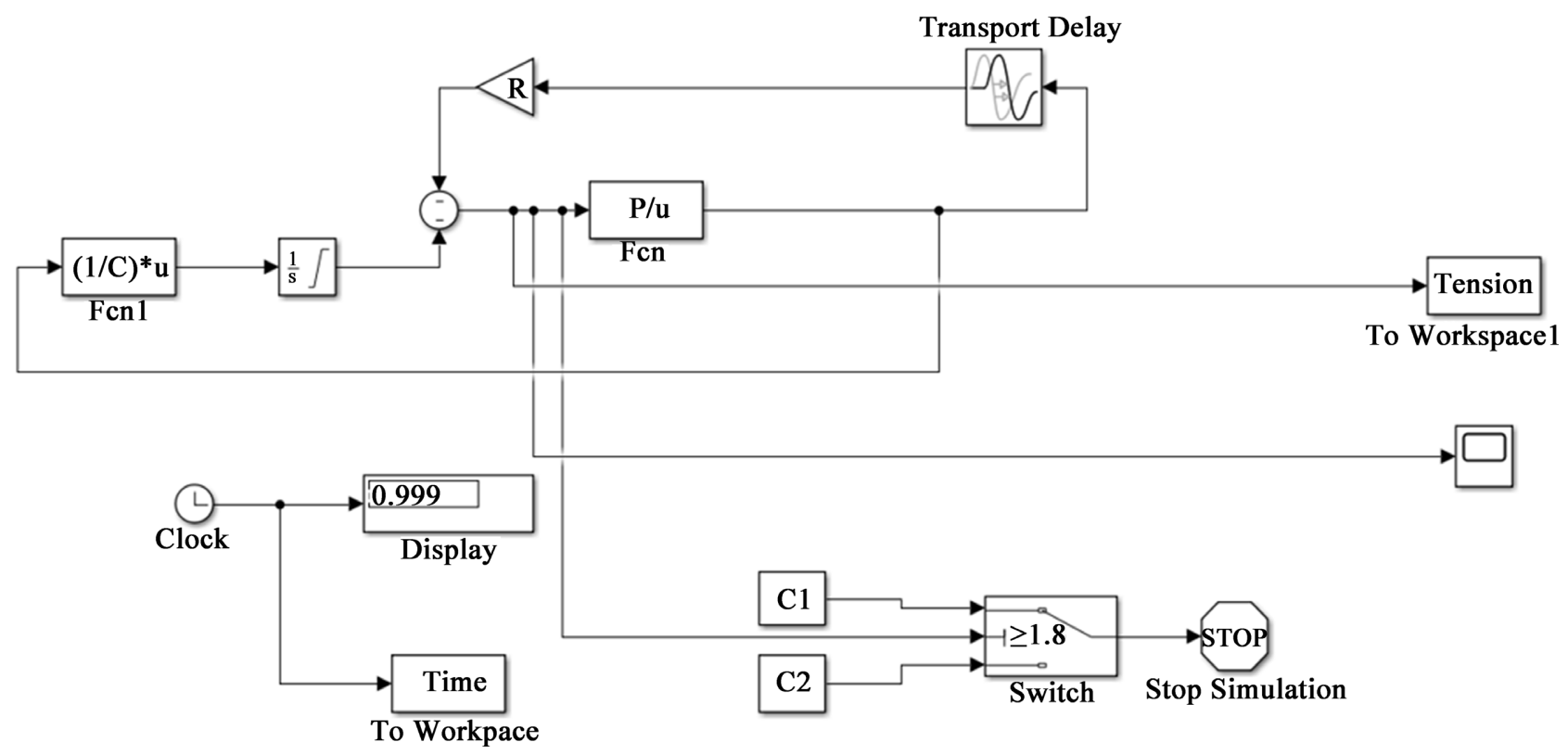

Figure 17. Model of the supercapacitor pack for 3-watt discharge.

Table 3. Discharge time at 3 watts depending on the number and assembly of supercapacitors.

\begin{tabular}{cccccccc}
\hline$N_{s c}$ & 1 & 2 & 4 & 6 & 8 & 10 & 3 \\
$N_{p}$ & 1 & 1 & 2 & 3 & 4 & 5 & 1 \\
$N_{s}$ & 1 & 2 & 2 & 2 & 2 & 2 & 3 \\
$C_{\text {pack }}(\mathrm{F})$ & 8.15 & 4.08 & 8.15 & 12.23 & 16.30 & 20.38 & 2.72 \\
$R_{\text {pack }}(\Omega)$ & 0.35 & 0.71 & 0.35 & 0.24 & 0.18 & 0.14 & 1.05 \\
$V_{\text {pack }}(\mathrm{V})$ & 2.5 & 5 & 5 & 5 & 5 & 5 & 7.5 \\
$T_{\text {discharge }}(\mathrm{s})$ & 1 & 9 & 25 & 39 & 55 & 69 & 15
\end{tabular}

supercapacitor pack can be determined. These values determined, are used in our model to simulate the discharge time to three watts depending on the number of supercapacitor (Figure 17) in series and/or parallel $\left(N_{s} \cdot N_{p}=N_{s c}\right)$.

For reasons of optimal sizing, the lowest capacity of a cell $\left(C_{s c}\right)$ is considered (Table 3 ) for the simulation. Also, our sensor needs a low voltage node around $3.3 \mathrm{~V}$ so the great tensions of the supercapacitor pack will not be considered. The results of the simulation at 3 watts, with the RC model whose modelling equations are given by (11)-(17), are reported in Table 3.

\section{Conclusion}

In this paper, we designed and simulated a solar energy recovery and storage system for powering wireless sensors. To achieve this, we have modelled each part, namely the solar panel, the adaptation circuit in which we used the disturb and observe command combined with the fuzzy logic for the search for the MPP and finally the supercapacitor for the storage of energy. The simulation results show that the control we used gives a better timing response than the traditional 
$\mathrm{P} \& \mathrm{O}$ control. The results also give the discharge time at 3 watts (required to power the wireless sensor) depending on the number and assembly of supercapacitor cells.

\section{Conflicts of Interest}

The authors declare no conflicts of interest regarding the publication of this paper.

\section{References}

[1] Rayonnement solaire à Saint-Louis (Sénégal) (tutiempo.net).

[2] Durand-Estèbe, P. (2016) Systèmes de récupération d'énergie pour l'alimentation de capteurs autonomes pour l'aéronautique. Micro et nanotechnologies/Microélectronique. INSA de Toulouse, Toulouse.

[3] Helali, K. (2012) Modelisation d'une cellule photovoltaique: Etude comparative. Doctoral Dissertation, Université Mouloud Mammeri, Tizi Ouzou.

[4] Navarro, J.M. (2008) Cellules photovoltaïques organiques transparentes dans le visible. Doctoral Dissertation, Université de Toulouse, Université Toulouse III-Paul Sabatier, Toulouse.

[5] Kety, K., Amou, K.A., Sagna, K., Tepe, K., Lare, Y. and Napo, K. (2016) Modélisation et simulation d'un générateur photovoltaïque: Cas du module polycristallin Ecoline LX-260P installé au dispensaire de Sévagan (Togo). Journal of Renewable Energies, 19, 633-645.

[6] Mambrini, T. (2014) Caractérisation de panneaux solaires photovoltaïques en conditions réelles d'implantation et en fonction des différentes technologies. Météorologie. Université Paris Sud-Paris XI.

[7] Telidjane, M. (2017) Modélisation des panneaux photovoltaïques et adaptation de la cyclostationnarité pour le diagnostic. Doctoral Dissertation, Université de Lyon, Lyon.

[8] Radjai, T., Gaubert, J.P., Rahmani, L. and Mekhilef, S. (2015) Experimental Verification of P \& O MPPT Algorithm with Direct Control Based on Fuzzy Logic Control Using CUK Converter. International Transactions on Electrical Energy Systems, 25, 3492-3508. https://doi.org/10.1002/etep.2047

[9] Macaulay, J. and Zhou, Z. (2018) A Fuzzy Logical-Based Variable Step Size P \& O MPPT Algorithm for Photovoltaic System. Energies, 11, 1340. https://doi.org/10.3390/en11061340

[10] Sindhura, L.S. and Chaudary, K. (2013) Artificial Neural Network Implementation for Maximum Power Point Tracking of Optimized Solar Panel. International Journal of Computer Applications, 78, 1-6. https://doi.org/10.5120/13522-1176

[11] Zandi, Z. and Mazinan, A.H. (2019) Maximum Power Point Tracking of the Solar Power Plants in Shadow Mode through Artificial Neural Network. Complex \& Intelligent Systems, 5, 315-330. https://doi.org/10.1007/s40747-019-0096-1

[12] Mahmod Mohammad, A.N., Mohd Radzi, M.A., Azis, N., Shafie, S. and Atiqi Mohd Zainuri, M.A. (2020) An Enhanced Adaptive Perturb and Observe Technique for Efficient Maximum Power Point Tracking under Partial Shading Conditions. Applied Sciences, 10, 3912. https://doi.org/10.3390/app10113912

[13] Kollimalla, S.K. and Mishra, M.K. (2014) A Novel Adaptive P \& O MPPT Algorithm Considering Sudden Changes in the Irradiance. IEEE Transactions on Energy 
Conversion, 29, 602-610. https://doi.org/10.1109/TEC.2014.2320930

[14] Hashim, N., Salam, Z., Johari, D. and Ismail, N.F.N. (2018) DC-DC Boost Converter Design for Fast and Accurate MPPT Algorithms in Stand-Alone Photovoltaic System. International Journal of Power Electronics and Drive Systems, 9, 1038. https://doi.org/10.11591/ijpeds.v9.i3.pp1038-1050

[15] Gualous, H., Gallay, R. and Berthon, A. (2004) Utilisation des supercondensateurs pour le stockage de l'energie embarquee: Applications transport. Revue de 1 Electricite et de l electronique, 8, 83-90. https://doi.org/10.3845/ree.2004.075

[16] El Mahboubi, F. (2018) Stockage adaptatif pour noeud de capteur sans fil autonome et sans batterie. Doctoral Dissertation, Université Paul Sabatier-Toulouse III, Toulouse.

[17] Belhachemi, F. (2001) Modélisation et caractérisation des supercondensateurs à couche double électrique utilisés en électronique de puissance. Micro et nanotechnologies/Microélectronique. Institut National Polytechnique de Lorraine INPL, Lorraine.

[18] Shili, S. (2016) Contrôle des circuits d'équilibrage des systèmes de stockage d'énergie (supercondensateurs) en vue d'estimer et d'améliorer leur durée de vie. Doctoral Dissertation, Université de Lyon, Lyon.

[19] Meekhun, D. (2010) Réalisation d'un système de conversion et de gestion de l'énergie d'un système photovoltaïque pour l'alimentation des réseaux de capteurs sans fil autonome pour l'application aéronautique. Micro et nanotechnologies / $\mathrm{Mi}$ croélectronique. INSA de Toulouse, Toulouse.

[20] Lachaize, J. (2004) Etude des stratégies et des structures de commande pour le pilotage des systèmes énergétiques à Pile à Combustible (PAC) destinés à la traction. Doctoral Dissertation. 